\title{
University Libraries Section at Midwinter A wrap-up of activities
}

\section{Executive Committee}

The University Libraries Section (ULS) Executive Committee, chaired by Carol Hughes, met twice during the ALA Midwinter Meeting. A large portion of the initial meeting focused on a discussion led by Lori Goetsch, chair of the ULS Standards and Guidelines Review Committee, and Linda TerHaar of the Undergraduate Librarians Discussion Group (UGLDG). In the past, ULS has been responsible for both the "Guidelines for Branch Libraries in Colleges and Universities," and the "Guidelines for Undergraduate Libraries." Since the "Guidelines for University Libraries" have been folded into the new "Standards for Libraries in Higher Education," the "Guidelines for Branch Libraries" are now obsolete. On the recommendation of the ULS Standards and Guidelines Review Committee, the Executive Committee voted during the meeting to rescind the "Guidelines for Branch Libraries," last revised in 1990.

To determine interest in and use of the guidelines, a call for feedback was published in CERL News in 2002, but little commentary was received. Before a final recommendation can be forwarded to the ACRL Standards and Accreditation Committee, and ultimately to the ACRL Board, a final call for comments is required. If you have any concerns about the rescission of these guidelines, please contact Lori Goetsch at lgoetsch@ksu.edu by May 1, 2005.

Linda TerHaar reported that librarians focused on services to undergraduates believe that separate guidelines are still important for them. UGLDG has proposed a new set of guidelines focused less on stand-alone undergraduate libraries and more on services to undergraduates in university libraries as a whole. The guidelines follow the structure of the "Standards for Libraries in Higher Education" and focus on assessment and outcomes. For more information about these guidelines, please contact Linda TerHaar at e-mail: terhaar@umich.edu.

Additional reports to the committee included information about the 2005 conference program, "Pay to Play-Debating Models for Scholarly Publishing." The program will be cosponsored by the ACRL Scholarly Communication Committee, and speakers include Marianne Gaunt of Rutgers University, Daniel Greenstein of the California Digital Library, and Heather Joseph of BioOne.

\section{Discussion groups}

ULS Discussion Groups were active and well attended at the Midwinter Meeting. The Current Topics Discussion Group presented "Institutional repositories: Their place in the evolution of scholarly communication" and featured a panel of speakers on various aspects of the issue. Michael Keller of Stanford University discussed is-

Leslie Madden is reference librarian at Georgia Institute of Technology and a member of the ULS communications committee, e-mail: leslie.madden@library.gatech.edu

(C) 2005 Leslie Madden 
sues related to creating Stanford's repository, including getting faculty to deposit materials, providing access, preserving materials, and hurdles to creating and maintaining the depository. Shane Nackerud of the University of Minnesota described UThink, the largest academic blogging site in America, and explained how the site was created and is being used. Margaret Branchofsky of Massachusetts Institute of Technology (MIT) presented information about DSpace, software created by MIT libraries in conjunction with Hewlett Packard, and explained how MIT is using DSpace for its repository.

The Public Services Directors of Large Research Libraries Discussion Group presented several topics for discussion. A primary topic focused on integrating library materials in course management Web tools. Several members discussed the "homegrown" systems used by their institutions, a representative of the University of Pennsylvania library discussed the pros and cons of maintaining a Web tools system (Blackboard), and a representative of Yale University led a discussion on "Sakai"-a new open source tool being developed by Indiana University, MIT, University of Washington, University of Michigan, and Stanford University.

The second topic of discussion related to marketing, public relations, and communications in libraries. Members from Harvard, Stanford, and Cornell universities discussed the creation of positions at their institutions to facilitate "branding" of library services, to serve as media contacts for the libraries, and to externally market the library.

A final discussion topic featured the Google Digitization Project. Much of the information about the project is still a closely held secret, but representatives from Harvard, University of Michigan, University of Virginia, and Stanford discussed how their faculty and institutions feel about the project and agreed that it is good for preservation. $\pi$
New from $\triangle C$ CR:

\section{CLIP Note \#35 Special Collections in College and University Libraries}

ISBN 0-8389-8314-6

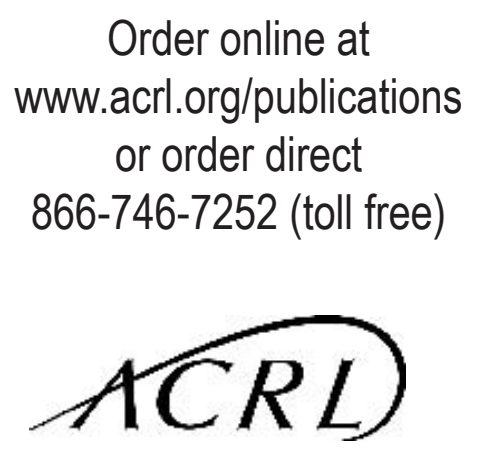

\section{Focus on $50+$}

AARP's

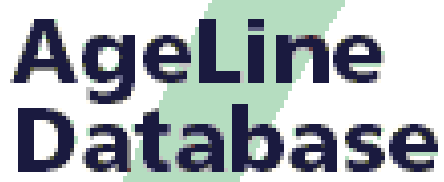

Social gerontology 8 aging-related research, policy, and practice

FREE searching at: www.aarp.org/ageline

Also available on CSA, Dialog, EBSCOhost, Ovid, B SilverPlatter agellnewarp.org 